\title{
18. IGNEOUS AND SEDIMENTARY ROCKS RECOVERED DURING DEEP SEA DRILLING PROJECT SITE SURVEYS OFF GUATEMALA ${ }^{1}$
}

\author{
Roland von Huene, Walter Friesen, and Charles Blome, U.S. Geological Survey, Menlo Park, California ${ }^{2}$
}

\begin{abstract}
Consolidated igneous and sedimentary rocks recovered during site surveys and with conventional sampling techniques consist of basaltic basement, late Albian to early Aptian radiolarian chert, and nannofossil limestone interbedded with volcanogenic sandstone and tuff. These samples add to the variety of rock types from the continental slope recovered by drilling; they indicate at least three additional outcrops of the igneous basement drilled beneath the Middle America Trench slope deposits during Leg 84.
\end{abstract}

\section{INTRODUCTION}

Glomar Challenger drilling of the Middle America Trench on Legs 66,67 , and 84 was preceded by site surveys conducted by scientists from the University of Texas and other institutions. Site investigations from the research vessel Ida Green included multichannel geophysical surveys (Ladd et al., 1982), sampling with a piston corer, and dredging during Legs IG24-5 and IG29-3. Studies of sediment recovered from 26 sampling stations off Guatemala have been reported by Enkeboll (1978) and McMillen et al. (1982). Some cores were reported to contain angular gravels of serpentine, basalt, and radiolarian chert. The one successful dredge on the flank of a seamount on the landward slope of the Trench near Site 570 contained limestone. If the seamount were volcanic, its position on the Trench slope rather than the volcanic arc is very peculiar. These samples took on a new significance after the recovery of Cretaceous limestones and serpentinized ophiolitic rock during Leg 84 (Aubouin, von Huene, et al., 1982), and it became obvious that the slope was composed of ophiolitic rock rather than accreted sediment. The absence of chert in cores from legs 67 and 84 with which to estimate the age of the ophiolitic rock was a disappointment. Therefore, we reexamined the piston cores and dredged samples from the site survey to establish the affinities of the igneous rock and to check the chert for an age-diagnostic fauna. Cores were examined with binocular microscope and major lithologies of interest were examined in thin section.

\section{DESCRIPTION OF SAMPLES FROM THE SEAMOUNT}

Bathymetry contoured from soundings along the 1977 survey tracks revealed a singular seamount (Fig. 1) on the upper slope of the Trench (McMillen et al., 1982). This seamount was subsequently crossed by the Glomar Challenger and then by the Thomas Washington during

\footnotetext{
${ }^{1}$ von Huene, R., Aubouin, J., et al., Init. Repts. DSDP, Washington (U.S. Govt. Printing Office),

2 Address: (von Huene, Friesen, and Blome) U.S. Geological Survey, Menlo Park, CA 94025 (prepared while the first author was visiting researcher at Laboratoire de Géologie Structurale, Université Pierre et Marie Curie, Académie de Paris).
}

a Seabeam survey (Volpe et al., this volume). The Seabeam map (Fig. 2) definitely established the location and oblong conical form of the seamount. Accurate location was important because satellite positions were acquired at infrequent intervals during the Ida Green operations (average 2 per day on IG24-4), with a resulting position uncertainty of at least $2 \mathrm{~km}$ (von Huene et al., this volume).

On McMillen's map (1982), Gravity Core 22 is plotted about $1 \mathrm{~km}$ east of the seamount. However, replotting the position on a large-scale copy of the McMillen map places Core 22 on the flank of the seamount. On the Seabeam map the Core 22 position is on the seamount, and its recorded depth is in good agreement with the Seabeam contours and the bathymetry taken by the Challenger. We consider the position of Core 22 to be as shown on the Seabeam map (Fig. 2), because this position is consistent with all of the original data.

Gravity Core 22, $94 \mathrm{~cm}$ long, consists of a coarse gravel containing angular clasts of basalt up to $3 \mathrm{~cm}$ across in a muddy matrix (Appendix). The texture indicates derivation of the angular clasts from pillowed submarine flows. Petrographic studies indicate that the basalt is not typical of a mid-ocean ridge basalt but contains significant clinopyroxene and some olivine in the groundmass of plagioclase, features more characteristic of an alkali basalt. The composition of the basalt in Gravity Core 22 is different from that at Site 570, approximately $1 \mathrm{~km}$ away, but the composition of the rock in Core 22 is consistent with the sharp magnetic anomaly associated with the seamount (Volpe et al., this volume).

About $15 \mathrm{~kg}$ of material were dredged from the seamount during the second year of work. The Ida Green position while dredging the seamount was probably more than $2 \mathrm{~km}$ in error. If plotted on McMillen's or the Seabeam maps, the recorded water depth during dredging is about $500 \mathrm{~m}$ shallower than that at the map position. A northward shift of about $2 \mathrm{~km}$ from the given position puts the dredge into proper water depths on the flank of the seamount. This is well within the navigational error established for other Ida Green positions (von Huene et al., this volume). 


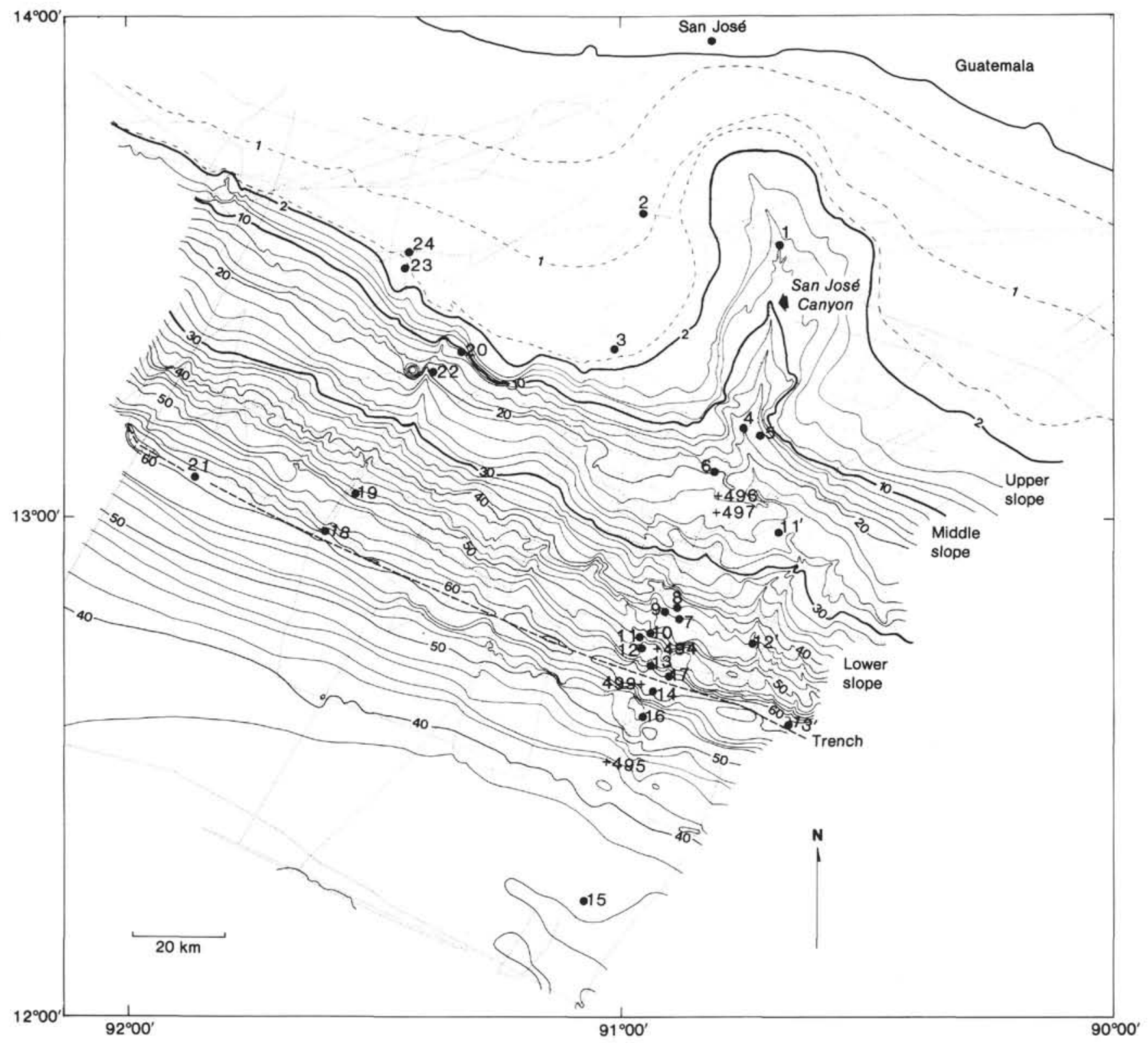

Figure 1. General bathymetric map (from McMillen et al., 1982), showing location of cores. Contours are at 200-m intervals.

Eighteen boulders of dredged rock were examined megascopically. All have broken faces, and some show bore holes and weathered faces. The predominant lithologies are dark red brown nannofossil limestone and moderately sorted fine- to coarse-grained volcanogenic sandstone and tuff. Because all 18 boulders contain the same rock types, the dredge probably sampled a single outcrop without boulders that were transported downslope. Sandstones are finely bedded to massive, and some thin beds are graded. Numerous small burrows are evident, but the original sediment structure was not destroyed by extensive bioturbation. The sand grains are angular and include red pumice, biotite, amphibole, feldspar, and glass.

Two thin sections containing the main lithologies apparent in hand specimen-a limestone, a calcareous siltstone, and a tuff-were studied. The pelagic limestone is structureless in thin section and contains many dispersed radiolarians and foraminifers. There is some alignment of biogenic material parallel to adjacent bedding. The calcareous siltstone is composed primarily of shell fragments and with some feldspar grains. Laminations are graded, and the upper part of the siltstone grades into the limestone. The siltstone has been burrowed, the burrows being filled with pelagic limestone. In thin section, the tuff consists of more than $90 \%$ devitrified glass shards and about $7 \%$ feldspar. The rock is grain-supported with most of the grains aligned.

The fine-grained sediment was deposited in quiet water receiving occasional volcanogenic detritus. An agediagnostic nannofossil flora recovered from five samples is late Turonian to early Maestrichtian $(\mathrm{K}$. McDougall, M. Filewicz, personal communication, 1982). Planktonic foraminiferal assemblages indicate a Maestrichtian 


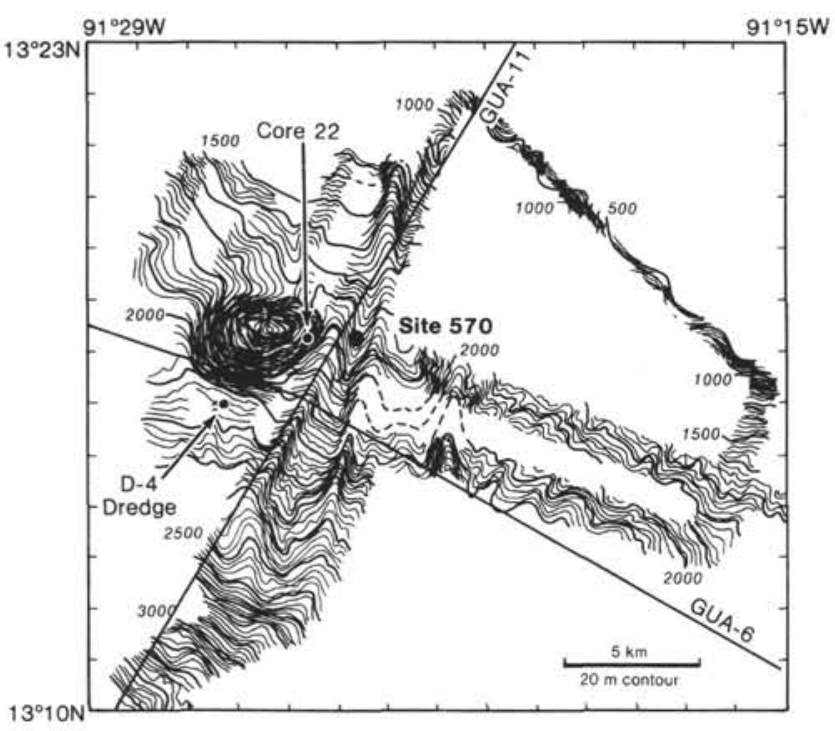

Figure 2. Bathymetry of the area around the seamount where gravity Core 22 and Dredge 4 (Station 10) were taken. Hole 570 is shown just east of the seamount (from Volpe et al., this volume). Contour interval $=20 \mathrm{~m}$. Track lines GUA-11 and GUA-6 from the network of site survey seismic records are shown.

age. Benthic foraminifers were transported from a bathyal environment to depths below the foraminiferal CCD (calcium carbonate compensation level, perhaps $3000 \mathrm{~m}$ ) (W. Sliter, personal communication, 1982).

Organic carbon contents of three samples measured by the direct organic-wet oxidation method are less than $0.5 \%$ organic carbon.

\section{DESCRIPTION OF SAMPLES FROM THE LOWER SLOPE}

Piston cores IG24-5-7 and IG24-5-9 (Cores 7 and 9, Fig. 1) have angular clasts of igneous rock and chert pebbles that warrant more detailed study than the macroscopic and preliminary microscopic studies of the preleg 84 reports (Enkeboll, 1978; McMillen et al., 1982). In these reports the clasts were described as metabasalt and metadiabase with lesser amounts of red radiolarian chert and serpentine (Appendix; Enkeboll, 1978). The samples were recovered from the lower slope of the Trench (Fig. 3). The core barrel appears to have hit the steep scarps that are formed on the lower slope in the area of the DSDP transect (Aubouin, von Huene, et al., 1982; von Huene et al., this volume). Along these scarps, the truncated ends of beds in slope deposits and basement are exposed as indicated in seismic records GUA-13 and GUA-18B. Piston Core 7 contains a section of many angular clasts from coarse sand to pebble size consisting largely of altered igneous rock. The angularity of clasts and consistent lithology suggest minimal transport. Chert makes up $5 \%$ of this section and is present in angular pebbles. The bottom of piston Core 9 consists of angular fragments that appear to fit together; this core may have sampled the top of a weathered outcrop.

Of the three samples examined for radiolarians, one contained identifiable late Aptian to early Albian (?) species. Because of low diversity and poor preservation, the age range was not determined within narrower limits. The assemblage includes Acaeniotyle umbilicata (Foreman), Archaeodictyomitra vulgaris Pessagno, Dictyomitra carpatica Lozyniak, Eucyrtis bulbosa Renz, Pseudodictyomitra lodogaensis Pessagno, Thanarla sp. aff. T. conica (Aliev), and Ultranapora durhami Pessagno, Xitus sp.

Two samples of the highly weathered material from piston Core 7 are metabasalt of similar composition, one of them originally very glassy and probably from a submarine flow, and the other from the interior of a flow.

\section{DISCUSSION}

The rocks collected in the predrilling site survey differ somewhat in composition from those drilled on Leg 84. Most of the igneous rocks obtained by drilling are of ultramafic composition, whereas igneous rocks recovered by conventional sampling from near the seafloor are basalts. Basalt from broken pillows typically occurs at high levels in ophiolitic sequences and is commonly overlain by chert and pelagic limestone. The association of basalt, chert, and pelagic limestone is thus consistent with their position at the top of an ophiolitic sequence. Similarly the absence of chert at the five drill sites may be consistent with the position of the ultramafic rocks lower in the sequence. The igneous rocks recovered in drill cores off Guatemala are probably from oceanic crust (Bourgois et al.; and Maury et al., this volume).

Only one of three chert samples contained an Albian diagnostic radiolarian assemblage. This age is consistent with the age of chert from similar rocks of the Nicoya and Santa Elena peninsulas of Costa Rica. The Nicoya complex has Cretaceous cherts, and the Santa Elena cherts are Albian-Turonian (Schmidt-Effing, 1980).

The recovery of Upper Cretaceous limestone from the flank of the seamount was surprising because it was not encountered in the nearby gravity core from sample station 22 (Fig. 1) and from Site 570. The Cretaceous limestone of Site 494 (Leg 67) and Site 567 (Leg 84) is thus more than a local occurrence, as was suggested by its absence above basement at Sites 569 and 570. The dredged limestone is more fossiliferous than its counterparts on the lower slope. Its benthic fauna were transported from an environment above the CCD into an environment below the CCD. The lower slope occurrences (Sites 494 and 567) do not record the frequent nearby volcanic activity. The limestone on the seamount has been uplifted from a depth below $3000 \mathrm{~m}$ to its present depth of 1600 $\mathrm{m}$; at one time it might have been near sea level, as suggested by numerous holes of boring animals.

The conical shape of the seamount and recovery of basalt from its eastern flank raise the possibility of a volcanic origin of this feature. However, the absence of any volcanic flows or layers of volcanic ejecta in the Eocene to Quaternary cores from Site 570 argue for a nonvolcanic or pre-Eocene volcanic origin of the seamount. The high resolution seismic data (Volpe et al., this volume) also indicate an origin for the seamount prior to deposition of Eocene and younger slope sediment. From the high-resolution seismic data, the seamount appears 


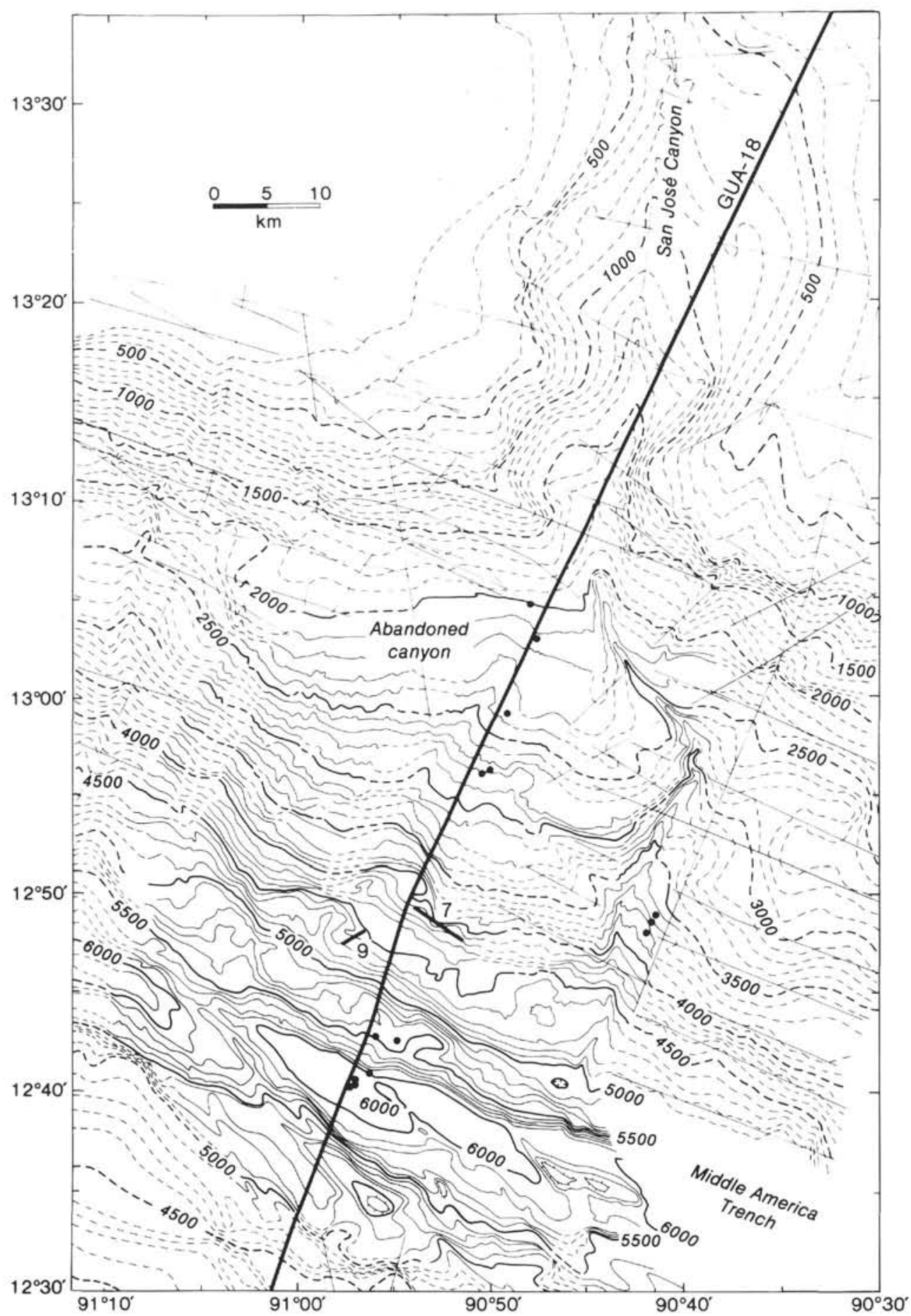

Figure 3. Topography in the area of piston Cores 7 and 9 showing path of the ship during coring. Other Leg 67 and Leg 84 sample stations are shown with dots (from von Huene et al., this volume); contour inter$\mathrm{val}$ is $100 \mathrm{~m}$.

to be a peak on the crest of a long ridge partly exposed above slope sediment. The midslope area has an unusually rugged basement topography that may have developed from deformation in the early Eocene (von Huene et al., this volume). The stratal continuity of the Cretaceous limestone appears disrupted by this deformation because it was not found nearby at Site 570 nor in the core from the east flank of the seamount.

\section{CONCLUSIONS}

The seamount near Site 570 is probably the exposed peak on the crest of a long ridge in the buried midslope deformed zone of the Guatemalan margin. It is less likely the top of a pre-Eocene volcano. The seamount exposes Cretaceous limestone on igneous ocean crust that forms the basement of the landward slope of the Trench. 
The Mesozoic radiolarian assemblage from the lower slope gives an approximate age that corresponds to some of the older radiometric age determinations on cored igneous rock (Maury et al., this volume). This Mesozoic basement and its Cretaceous cover appear to have been tectonically disturbed prior to being covered by the main body of slope sediment. Thus igneous rocks were recovered with conventional oceanographic techniques from three sites on the landward slope of the Middle America Trench, thereby increasing the number of localities where the ophiolitic basement is known to eight.

\section{REFERENCES}

Aubouin, J., Stephan, J. F., Renard, V., Roump, J., and Lonsdale, P., 1982. A Seabeam survey of the Leg 67 area (Middle America Trench off Guatemala). In Aubouin, J., von Huene, R., et al., Init. Repts. DSDP, 67: Washington (U.S. Govt. Printing Office), 733-738.

Aubouin, J., von Huene, R., Baltuck, M., Arnott, R., Bourgois, J., Filewicz, M., Kvenvolden, K., Leinert, B., McDonald, T., McDougall, K., Ogawa, Y., Taylor, E., and Winsborough, B., 1982. Leg 84 of the Deep Sea Drilling Project, subduction without accretion: Middle America Trench off Guatemala. Nature, 297:458-460.

Enkeboll, R. H., 1978. Sedimentary petrology of sands from the Middle America Trench and trench slope: Guatemala and southern Mexico (Masters thesis). University of California, Santa Cruz.

Ladd, J. W., Ibrahim, A. K., McMillen, K. J., Latham, G. V., and von Huene, R. E., 1982. Interpretation of seismic reflection data of the Middle America Trench offshore Guatemala. In Aubouin, J., von Huene, R., et al., Init. Repts. DSDP, 67: Washington (U.S. Govt. Printing Office), 675-690.

McMillen, K. J., Enkeboll, R. H., Moore, J. C., Shipley, T. H., and Ladd, J. W., 1982. Sedimentation in different tectonic environments of the Middle America Trench, southern Mexico and Guatemala. In Leggett, J. K. (Ed.), Trench-Forearc Geology. Geol. Soc. London Spec. Publ. 10(Blackwell).

Schmidt-Effing, R., 1980. Radiolarian der Mittle-Kreide aus dem Santa Elena Massev von Costa Rica. Neues Jahrb. Paläont. abh. Stuttgart, 160(2):241-257.

Date of Initial Receipt: 30 January 1984

Date of Acceptance: 1 June 1984

\section{APPENDIX}

Core Descriptions and Annotations ${ }^{3}$

Piston core: IG24-5-7

Position: $12^{\circ} 49.3^{\prime} \mathrm{N}$; $90^{\circ} 52.7^{\prime} \mathrm{W}$

Corrected depth: $2259 \mathrm{fm}$

PDR depth: $2208 \mathrm{fm}$

Date taken: 28 May 1977

Date opened and described: 27 September 1977

Core length: $374 \mathrm{~cm}$

Penetration: $\sim 400 \mathrm{~cm}$

Flow-in: $0 \mathrm{~cm}$

Summary of core: very coarse gravelly radiolarian ash-sandy mud, olive gray (5Y $3 / 2)$, extremely soft and watery consistency at top of core. Poor sorting in this uppermost unit, with large chunks of serpentine, basalt, and chert present. This unit followed by a fine to very fine radiolarian sandy clay, olive gray (5Y 3/2), from 39$148 \mathrm{~cm}$. No gravel size material present in this unit. From 148-190 $\mathrm{cm}$ there is very coarse muddy gravel with a large amount of rock fragments, grading into a larger grain size in the lowermost unit of this core, which is a very coarse gravel, mud content nil. Rock fragments of serpentine, chert, sandstone, and basalt are present in abundant numbers with only rare amounts of glass shards and

\footnotetext{
${ }^{3}$ Core descriptions by T. Haines when cores were first opened at the University of Texas Laboratories (1977). Annotation by R. von Huene during inspection and sampling, 1982.
}

opaque minerals. No visible structures evident. Stratigraphic positioning of units in this core possibly is the result of a debris flow or turbidity current.

Interval

Description

$0-39 \mathrm{~cm}$

Very coarse to very fine gravelly radiolarian ashsandy mud, olive gray (5Y $3 / 2$ ), extremely soft and watery. Sediment of this unit only partially fills liner halves, thus disturbance of original stratigraphy is very probable. Very coarse pebble size of rock fragments of serpentine, colored dark greenish gray ( $5 \mathrm{G} 4 / 1)$, present in this poorly sorted unit. At the basal contact, there is a sharp change in texture and composition.

39-148 cm Fine to very fine radiolarian sandy clay, olive gray (5Y $3 / 2)$, very soft and moist. No visible structures evident. This material is very homogeneous, unburrowed; no gravel present. At the basal contact there is a very distinct change in color, texture, and composition.

$148-190 \mathrm{~cm}$ Very coarse, muddy gravel, colored between the dark greenish grays (5GY $4 / 1$ and $5 \mathrm{G} \mathrm{4/1)}$ ). Loose grains and granules with low moisture content. Grain size ranges from a medium sand to $0.5 \mathrm{~cm}$, on the average. No visible structures in this unit. Rock fragments primarily serpentine with rare amounts of chert; grain size gradually becomes coarser with depth. At this basal contact, there is a gradual change in composition.

$190-374 \mathrm{~cm}$ Very coarse angular gravel colored between the (core bottom) dark greenish grays (5GY $4 / 1$ and $5 \mathrm{G} 4 / 1$ ). No mud in this unit; clean rock fragments abundant. Grain size ranges from $0.25 \mathrm{~cm}$ to $3.5 \mathrm{~cm}$ in diameter on the average. Sorting is poor with no indication of grading evident. Mud content is nil through this unit.

Piston core: IG24-5-9

Position: $12^{\circ} 49.9^{\prime} \mathrm{N} ; 90^{\circ} 55.6^{\prime} \mathrm{W}$

Corrected depth: $2325 \mathrm{fm}$

PDR depth: $2270 \mathrm{fm}$

Date taken: 29 May 1977

Date opened and described: 23 September 1977

Core length: $55 \mathrm{~cm}$

Penetration: $420 \mathrm{~cm}$

Flow-in: $0 \mathrm{~cm}$

Summary of core: medium coarse to medium fine muddy serpentine sand, dark greenish gray (5G 4/1), semisoft and moist. Top unit of core is graded to coarser material with depth. Lower unit is an extremely coarse muddy serpentine gravel with rock fragments up to several centimeters in length. Coarse fraction yields an abundance of sand-size serpentine rock fragments, rare amounts of dark and opaque minerals, quartz, feldspar, pyrite, obsidian, and glass shards. No visible structures evident in these units. (The gravel is probably the weathered top of the serpentinite, which broke up during coring and splitting of the core; so the gravel is nonsedimentary.)

Interval

Description

0-15 cm Medium coarse to medium fine muddy serpentine sand, dark greenish gray (5G 4/1), semisoft and moist; a 1-cm-thick dark greenish gray (5GY $4 / 1$ ) surface veneer is present at the very top $1 \mathrm{~cm}$ of core (possibly the result of oxidation). Unit is graded to medium coarse material at base. At the basal contact, there is a gradual change in texture, and composition. 
Interval

Description

$15-55 \mathrm{~cm}$

(core bottom)
Extremely coarse muddy serpentine gravel, dark greenish gray (5G 4/1) loose fragments of rock abundant; most chunks have angular edges. (Much of it is highly weathered.)

Piston core: IG24-5-22

Position: $13^{\circ} 17.4^{\prime} \mathrm{N} ; 91^{\circ} 24.5^{\prime} \mathrm{W}$

Corrected depth: $883 \mathrm{fm}$

PDR depth: $870 \mathrm{fm}$

Date taken: 2 June 1977

Date opened and described: 19 October 1977

Core length: $94 \mathrm{~cm}$

Penetration: $115 \mathrm{~cm}$

\section{Flow-in: $0 \mathrm{~cm}$}

Summary of core: very coarse muddy gravel, greenish black (5G 2/1), loose-grained with low moisture content; very poorly sorted with particle size ranging from a coarse sand to rock fragments $3 \mathrm{~cm}$ in diameter; upper unit appears to exhibit vague grading to a larger material toward its base; lower unit is a medium coarse to very fine gravelly foraminiferal sandy mud ( 25 to $94 \mathrm{~cm}$ ), dark greenish gray (5GY 4/1), semisoft and moist, burrowed with fill material more coarse than adjacent matrix and colored greenish black (5G $2 / 1$ ) to greenish black ( 5 GY 2/1) from 40 to $86 \mathrm{~cm}$; sparse number of dusky yellow green ( $5 \mathrm{GY} 5 / 2$ ) colored mottled areas present at 46 and $58 \mathrm{~cm}$; shell debris at $26 \mathrm{~cm}$; several large rock fragments (3 $\mathrm{cm}$ in diameter) present in random locations in lower unit; no visible sedimentary structures evident; abundant rock fragments noted throughout core with rare or common amounts of foraminifers, manganese, glass shards, diatoms, pyrite, mica flakes, glauconite, and pteropods.

Interval

Description

$0-25 \mathrm{~cm}$

Very coarse muddy gravel, greenish black (5G 2/1), loose-grained, low moisture content; very poor sorting present in unit, with a particle size that ranges from a coarse sand to $3 \mathrm{~cm}$ in diameter; rock fragments very common; grain size increases with depth. At the basal contact, there is a gradual change in color, texture, and composition.

$25-94 \mathrm{~cm}$ (core bottom)

Medium coarse to very fine gravelly foraminiferal sandy mud, dark greenish gray (5GY 4/1), semisoft and moist; burrowed areas with coarse fill material colored greenish black (5G 2/1) are present from 40 to $86 \mathrm{~cm}$, ranging from 0.50 to $2.50 \mathrm{~cm}$ in diameter; some dusky yellow green (5GY 5/2) colored mottling present at 46 and $58 \mathrm{~cm}$; shell debris (molluscan) noted at $26 \mathrm{~cm}$ in low amounts; large 3-cm-diameter rock fragments floating in muddy matrix occur throughout this unit; no visible sedimentary structures evident. 